\title{
Tracing the Labor Absorption Rate in the Medium and Large Industrial Sectors
}

\section{EcceS: \\ Economics Social and Development Studies}

\author{
Sitti Aisyah ${ }^{1}$ \\ Sulastri ${ }^{2}$ \\ Department of Economics, Faculty of Economics and Islamic Business, \\ UIN Alauddin Makassar, Indonesia ${ }^{\mathbf{1 , 2}}$ \\ e-mail: icaiwan68@gmail.com \\ (Article history) Received: 2020-12-11, Revised: 2020-12-24, Accepted: 2020-12-25, \\ Available online: 2020-12-26, DOI: https://doi.org/10.24252/ecc.v7i2.16286, \\ http://journal.uin-alauddin.ac.id/index.php/ecc/index
}

\section{Abstract: Tracing the Labor Absorption Rate in the Medium and Large Industrial Sectors}

The high rate of population growth and the workforce raises the problem of job opportunities, because it involves various aspects both economic and non-economic. At the same time as massive industrialization, it is not automatically able to create adequate work. This study aims to analyze and determine the effect of the number of business units, the provincial minimum wage, and economic growth on the rate of labor absorption in the medium and large industrial sectors in South Sulawesi in the period 2010-2019. This research is expected to be one of the benchmarks for the government and private sector in paying attention to the absorption rate of labor in the industrial sector in South Sulawesi. The type of research used in this research is quantitative. The type of data used in this study is secondary data. The data used in this study are time series data in the years 20102019. The results of this study indicate that (1) the number of business units has a positive and significant effect on the rate of employment in the industrial sector in the province of South Sulawesi, (2) the provincial minimum wage has a negative and significant effect on the rate of employment in the medium and large industrial sector in South Sulawesi, (3) economic growth has a significant effect in a negative direction on employment in the medium and large industrial sectors in South Sulawesi. The government should design an industrialization policy direction that should be more inclusive, the incoming investment should be based on empowering local workers, reducing unemployment, creating more expansive employment opportunities and synergizing local economic development.

Keywords: Economic Growth; Industry; Labor; Wages. 
Sitti Aisyah, Sulastri, Tracing the Labor Absorption Rate in the Medium and Large Industrial Sectors.

\section{INTRODUCTION}

Economic development is basically a change that applies both from the aspect of economic activity such as the development of education, the development of improved technology in health, an increase in the availability of infrastructure and an increase in income and community prosperity Economic development is a method used by the government to help realize more economic growth. advanced and is a tool used to encourage economic growth (Sukirno, 2016).

Economic development in developing countries characterized by increasing unemployment is a more complex and more serious problem than the problem of changes in the distribution of income that are less favorable for low-income people. The conditions in the developing country over the past few decades show that economic development is unable to create job opportunities faster than population growth. This can cause several problems in business development because on the one hand a high population growth rate will cause the development of the number of workers to be almost as fast, on the other hand the country's ability to create new job opportunities is very limited (Sukirno, 2006).

The high rate of population growth and the high labor force means that the problem of job opportunities will arise, because existing job opportunities are very important in terms of various aspects, both economic and non-economic. In addition, efforts to expand job opportunities are one of the efforts to improve living standards. The instability that occurs between the increase in available job opportunities has resulted in an increasingly compelled need to expand employment opportunities.

In the terminology of the Indonesian Central Statistics Agency (2019), what is meant by job opportunities is the number of people who are able to work for a company or agency. This job opportunity will accommodate all available workers, if the available employment opportunities are in balance with the number of available workers. A

In addition, what is meant by employment is a field of business activity or workers or institutions where someone works or has worked. According to Todaro (2003) there are three main components that can affect economic growth in every country, the first is the accumulation of capital which includes all forms or types of investment that have just been invested in land, physical equipment and human capital, secondly population growth which can affect the amount of investment. workforce, all three technologies. 
Labor is an important player in the establishment of a company. In a human company there needs to be a community of one and another to achieve something that has become their goal. As with companies, companies also have a goal of wanting to get as much profit as possible.

Labor problems are problems that will always be faced by every company, an industry that relies on talent, skills, and creativity which are the basic elements of every human being. Large and modern companies have used machines or automatic tools to computers, but those who control the running of these machines are humans (Rakhmawati \& Arfida, 2018). The number of medium and large industrial sector labor absorption in South Sulawesi Province fluctuates quite a bit from year to year. In 2011 it reached 0.96 percent and decreased in 2018 to 0.01 percent and again increased in 2019 to 0.26 percent.

Table 1

Medium and Large Industrial Sector Labor Absorption

in South Sulawesi Province for the period 2011-2019

\begin{tabular}{ccc}
\hline Year & Total manpower & Percentage of growth (\%) \\
\hline 2011 & 38.838 & 0,96 \\
\hline 2012 & 56.436 & 0,45 \\
\hline 2013 & 56.968 & 0,09 \\
\hline 2014 & 57.540 & 0,01 \\
\hline 2015 & 49.346 & $(0,14)$ \\
\hline 2016 & 63.219 & $(0,02)$ \\
\hline 2017 & 47.157 & $(0,02)$ \\
\hline 2018 & 46.340 & $(0,01)$ \\
\hline 2019 & 33.940 & $(0,26)$ \\
\hline
\end{tabular}

Source: Badan Pusat Statistik Sulawesi Selatan, 2020.

In the year PDRB based on the business field in the industrial sector has increased every year, the lowest in 2010 was $23,604,460$ billion with a percentage and the highest was in 2019 at $44,832,070$ with a growth percentage of 0.99 from 2018. One measure of the success of a economic development with industrialization means more job opportunities 
Sitti Aisyah, Sulastri, Tracing the Labor Absorption Rate in the Medium and Large Industrial Sectors.

are opened. Even though it is impossible to achieve, the ideal condition close to unemployment is trying to be achieved. Labor absorption is the amount of labor used by a sector or business unit. The ability to absorb labor is a model of demand for a business unit for labor in the labor market which is influenced by the prevailing wage rate (Purwasih and Soesatyo, 2017).

Table 2

Percentage of GRDP Growth in Industrial Sector Based on Constant Prices in the Period 2010-2019

\begin{tabular}{cccc}
\hline No & Year & $\begin{array}{c}\text { Total PDRB } \\
\text { (Billion Rp) }\end{array}$ & $\begin{array}{c}\text { Percentage of } \\
\text { growth PDRB (\%) }\end{array}$ \\
\hline 1 & 2010 & $23,604,460$ & - \\
\hline 2 & 2011 & $25,736,566$ & 0,90 \\
\hline 3 & 2012 & $27,966,146$ & 0,86 \\
\hline 4 & 2013 & $30,545,257$ & 0,92 \\
\hline 5 & 2014 & $33,293,323$ & 0,89 \\
\hline 6 & 2015 & $35,547,211$ & 0,67 \\
\hline 7 & 2016 & $38,473,771$ & 0,82 \\
\hline 8 & 2017 & $40,407,185$ & 0,50 \\
\hline 9 & 2018 & $40,788,012$ & 0,09 \\
\hline 10 & 2019 & $44,832,070$ & 0,99 \\
\hline
\end{tabular}

Source: Badan Pusat Statistik Sulawesi Selatan, tahun 2020.

The success of a country in terms of development can be seen by how big the role of the government is to be able to create and increase jobs and reduce unemployment, with the creation of new jobs and increasing food, it will have an impact on the absorption of the existing workforce so that there is an increase in income and an increase in power. buying which has an impact on increasing people's welfare (Paramita and Putu, 2009).

The limited employment opportunities available in the province of South Sulawesi are not in balance with the current increase in the workforce so that the impact can be seen from the high number of unemployment. Basically, the high number of unemployed will have an impact on economic development which has a series of measures and policies aimed at improving people's lives. The policy of expanding employment opportunities is a policy for the implementation of development because one of the benchmarks for assessing 


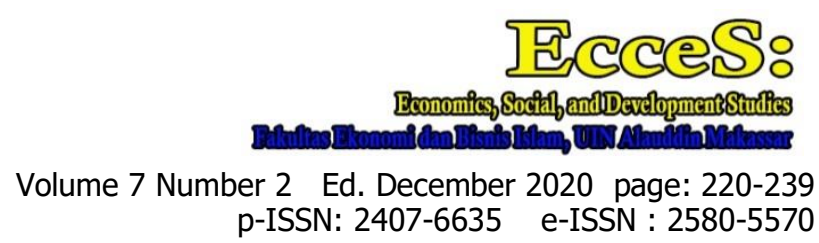

the economic success of a region is the job opportunities created by economic development (Saputri and Rejekiningsih, 2007).

The main and fundamental problems facing Indonesia are the problem of low wages and high unemployment and a continuing population growth. This is due to the fact that the addition of new workers is far greater than the growth in existing employment every year.

In general, the UMP in South Sulawesi Province has increased from year to year, this can occur in line with the high prices of various kinds of people's necessities of life. Each year, it increases to around Rp. 200,000 each year. However, in reality the amount of wages that have been determined is not necessarily sufficient for the life of the workforce.

The demand for labor has a relationship between the level of wages and the number of workers desired by employers to be employed. The firm's demand for labor is in contrast to consumer demand for goods and services. People buy goods because they provide satisfaction or utility to the buyer. However, business actors employ someone because that person can help produce goods or services to sell to consumers. In other words, the increase in demand by business actors for labor depends on the increase in public demand for goods (Payaman, 2002).

\section{THEORETICAL REVIEW}

According to Adam Smith's view in Payaman (2002) and Sumarsono (2003) states that in maximizing profits each company uses production factors in such a way that each production factor used receives or is given a reward equal to the value of the marginal increase The production factor, or in other words, the workforce earns a wage equal to the increase in results. Changes in the wage rate will affect the level of the company's production costs. If we use the assumption that the wage rate increases, several things will happen. The increase in the wage rate will increase the company's production costs, which in turn will increase the price per unit of goods produced. Usually, consumers will respond quickly if there is an increase in the price of goods, namely reducing their consumption or even no longer wanting to buy the item.

Classics like Adam Smith, David Ricardo and Thomas Robert Malthus were of the opinion that there is always a race between the level of development of output and the level of development population which was eventually won by population development. Since residents also function as labor, there will be difficulties in employment. If the resident can 
Sitti Aisyah, Sulastri, Tracing the Labor Absorption Rate in the Medium and Large Industrial Sectors.

get a job, then this will improve the welfare of the nation. But if you don't get a job means they will be unemployed, and it will suppress the standard of living of their nation even more low. The dimensions of the labor problem are not just limited fields or opportunities work and low productivity but far more serious, with different causes. In the past decade, the main problem lies in the failure to create jobs new at a rate proportional to the growth rate of industrial output. along with changing macroeconomic environment for the majority of developing countries.

Classical economists claim that labor / employees base the supply of labor on the basis of real wages (W / P). Therefore, an increase in nominal wages will not change the supply of labor if it increases the wage is accompanied by an equivalent price level. People who feel more rich because the increase in nominal wages and increases in the price level of the same is said as a money illusion. A rational person will not be exposed to the illusion of money because they only want to change the supply of labor when it happens changes in real wages.

As a result, many goods are not sold, and producers are forced to reduce their production. Lower production targets, resulting in reduced workforce required. The decrease in the number of workers needed due to the effect of the decrease in the scale of production is called the scale effect. If wages increase (assuming the prices of other capital goods do not change), there are entrepreneurs who prefer to use capital-intensive technology for their production processes and replace labor with capital goods such as machinery and others, a decrease in the amount of labor required due to the change / addition of the use of machines is called the substitution effect.

The increase in wages will be accompanied by a decrease in demand for labor, which means that it will cause an increase in the number of unemployed. Likewise, on the contrary, with a decrease in wages it will be followed by an increase in employment opportunities, so that it will be said that employment opportunities have an inverse relationship with the wage level. An increase in the level of wages accompanied by an increase in labor will only occur if a company is able to increase the selling price of goods (Payaman, 2002).

In contrast to Marshall's view in Taschereau-Dumouchel (2015), Todaro (2003), and Hau et al., (2017) that neoclassical economists introduce the concept of utility. This concept does not exist in classical economics. In their analysis, classical economists emphasized the production of goods and services. It differs from neoclassical economics, which takes into 


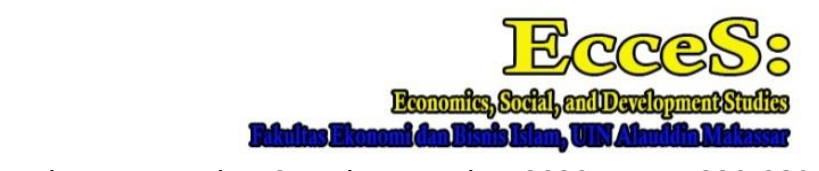

Volume 7 Number 2 Ed. December 2020 page: 220-239 p-ISSN: 2407-6635 e-ISSN : 2580-5570

account individual actions and decisions. Efforts to maximize utility determine actions and decisions. Neoclassical assumes flexible wages and prices. Neoclassical economics focuses on long-term economic activities. Such flexibility implies that the aggregate supply has vertical lines. The price level has no effect on real GDP. An increase in aggregate demand will not result in higher real GDP. Low wages reduce production costs. With lower production costs, businesses are eager to increase production. As a result, they will try to boost production and gradually recruit a workforce. Higher demand slowly raises wages. Finally, when production returns to normal, the short-term equilibrium will return to its potential level. Likewise, when short-run aggregate supply is above its potential output, the nominal wage rate increases. Higher salaries increase production costs, and hence lower profit margins.

The neoclassical idea states that in order to maximize profits, each entrepreneur uses the factors of production in such a way that each production factor used receives or is rewarded with the added value of the marginal yield of the production factor. This means that the employer employs such a number of employees that the value added of a person's marginal output equals the wages that person receives. So it can be concluded that according to the Neo Classical theory, workers earn wages equal to their marginal value added. In other words, the wage in this case functions as a reward for the work effort the person gives to the entrepreneur. To maximizing the profit of each entrepreneur using the factors of production in such a way that each factor of production isused to receive or be rewarded with added value the marginal yield of these factors of production. Employers are hiring the number of employees in such a way that value added results a person's marginal equals the wages that person receives. Theory Marginal productivity implies that additional production costs are paid to the factors of production is the same as the proceeds from sales extras obtained from additional production created by these production factors.

From the above concept, the term Marginal Product of labor (MPL), which is the additional output received by the company as a result of adding one unit of input. In view Classically, this MPL is considered to be the same as the real wage received by labor (MPL = $\mathrm{W} / \mathrm{P}$ ). This theory is based on the principle of value the increase in the marginal yield of the factor of production, where wages are compensation for the added value of production received by the company from employees. 
Sitti Aisyah, Sulastri, Tracing the Labor Absorption Rate in the Medium and Large Industrial Sectors.

Meanwhile, Keynes's view in Mankiw (2006) Meanwhile, Keynesian economists focus on short-run economic phenomena and assume wages and prices are sticky. Wages are inflexible and cannot go up and down according to economic conditions. One of the causes of wage stickiness is the contract system. For example, when workers work, they get a salary and the company will adjust it once a year, depending on economic conditions. When the next quarter of economic growth picks up high, you certainly can't renegotiate higher wages. Conversely, when the next quarter of the economy falls, the company will not necessarily reduce the salaries of these workers. According to Keynes, lowering wages will result in pension.

Government involvement in the economy has long been important topic in the history of economic thought. Classical School with the slogan laissez-faire laissez-passer emphasizes or wills minimize government interference in the country's economy. This school believes that economic problems should be completely left to market mechanism, without government intervention. Since formulated by Adam Smith in the early 18th century, school classical is very dominant in world economic thought, until it happens the great economic depression of the 1930's. This economic depression has dismantled laissez-faire logic and gave birth to the Keynesian school. The logic is that the market mechanism will always be able to sustain the economy in an ideal level, as classical school belief, undermined by Keynes's view that justifies interference government. It even surfaced the thought that the economy who only rely on market mechanisms alone, can fall into in prolonged depression, and is not automatically able to rise to conditions of full employment. This happened, among other things, because the perfect competition market as imagined so far will never materialize. This Keynesian consensus tries to correct weaknesses classical logic of thought. If the previous consensus put the entire burden of goal realization on the market, Keynesian puts that burden on the shoulders of the government, which is in it maximize the role of government in reducing market failures. This includes government spending to create job opportunities and minimize unemployment and improve wages (Mankiw, 2006).

\section{METHODS}

This research is a type of quantitative research, namely research activities in an effort to reach conclusions on the proposed hypothesis by analyzing quantitative data. This type of research is library research. In this study, the location of the research taken is the 


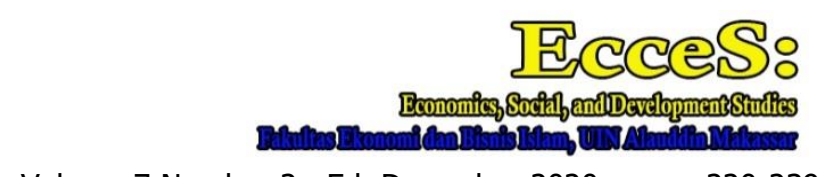

Volume 7 Number 2 Ed. December 2020 page: 220-239 p-ISSN: 2407-6635 e-ISSN : 2580-5570

province as a whole, while the data collection process for data on labor absorption, the number of business units, economic growth and minimum wages can be done at the Department of Industry and Trade of South Sulawesi Province and from the Provincial Statistics Agency (BPS). South Sulawesi.

The type of data used in this study is secondary data which is time series in the form of an annual from 2010-2019. Secondary data is data that supports primary data, namely all forms of data obtained through literature in the form of magazines, journals, articles or from various previous research results related to the discussion in this thesis. Data collection was carried out to obtain the data needed in this study. The data collection method in this research is through literature study. Literature study is carried out by collecting information through literature, notes, comments and others that are relevant to the object of this research. The data used are secondary data in annual form from each variable obtained in a finished form from the Central Statistics Agency (BPS) of South Sulawesi Province.

The method used to analyze between these variables is using the Ordinary Least Square (OLS) method. Where in this method Ordinary Least Square (OLS) is to test the effect of two or more independent variables on one dependent variable. This study uses multiple linear analysis with time series data. Multiple linear analysis is used to analyze the magnitude of the relationship and the effect of more than two independent variables on the dependent variable. The use of multiple regression is to examine the effect of independent / independent variables (economic growth, number of business units, and wages). The technique used is multiple regression with the following equation:

$Y=f(X 1, X 2, X 3)$ 1.1

It can be explicitly stated in the Cobb-Douglas function as follows:

$Y=a+\beta 1 X 1+\beta 2 X 2+\beta 3 X 3+\varepsilon$

The equation above is often called the Cobb-Douglas production function. To make it easier to predict the equation above, the equation is broadly expanded and converted into a linear form by analyzing the equation (Soekartawi, 2003: 48), namely:

$\operatorname{LnY}=\beta 0+\beta 1 \operatorname{LnX} 1+\beta 2 \operatorname{LnX} 2+\beta 3 \operatorname{LnX} 3+\varepsilon$ 
Sitti Aisyah, Sulastri, Tracing the Labor Absorption Rate in the Medium and Large Industrial Sectors.

Which is:

\begin{tabular}{|c|c|}
\hline $\operatorname{LnY} \quad=$ & Labor absorption logarithm \\
\hline$\beta 0$ & Constant \\
\hline LnX1 & Logarithm of the number of units of work \\
\hline $\operatorname{LnX} 2$ & Logarithm of wages \\
\hline LnX3 & Logarithm of industrial sector economic growth \\
\hline $1, \beta 2, \beta 3$ & $=$ Independent variable coefficient \\
\hline$=$ & Confounding Variable \\
\hline
\end{tabular}

RESULTS AND DISCUSSION

The working age population in the South Sulawesi region in 2011 was 5,575,602 people. Of the total working age population, 3,612,424 people are included in the labor force, or more than $50 \%$ of the total working age population. Of the entire workforce, 236,926 people are still looking for work. From this figure, it can be calculated that the open unemployment rate in South Sulawesi Province in 2011 was 6.56\%. Then in 2018 the working age population totaled 3,988,029 people and included in the working workforce amounted to $3,774,924$ people from the entire workforce, it is recorded that 213,105 are still looking for work. In 2019 the population of working age increased to 4,030,400, an increase of 42,371 compared to 2018, then the working population in 2019 was 3,830,096 (Badan Pusat Statistik Sulawesi Selatan, 2020).

Minimum wage is a minimum (lowest) monthly income as a reward from employers to employees, for a job or service that has been or will be performed. Expressed in the form of money determined based on an agreement or statutory regulation, and paid based on a work agreement between the entrepreneur and the employee, including benefits, both for the employee himself and his family. The increase in wages that occurred every year began in 2010 which had an increase in the range of 100,000 then was followed by subsequent years which increased by around 200,000 per year. Economic growth is a process of increasing per capita output over a long period of time. Economic growth includes 3 aspects, 
namely: 1) Economic growth is a process (economic aspect) of a developing economy; 2) Economic growth is associated with an increase in outpur per caputa, in this case total output and population; and 3) Economic growth is associated with a long-term perspective (Boediono, 1992).

Table 3

Amount of Provincial Minimum Wage and Number of Workers Industrial Sector in South Sulawesi Province

\begin{tabular}{cc}
\hline Year & Provincial minimum wage \\
\hline 2010 & 1.000 .000 \\
\hline 2011 & 1.100 .000 \\
\hline 2012 & 1.200 .000 \\
\hline 2013 & 1.440 .000 \\
\hline 2014 & 1.800 .000 \\
\hline 2015 & 2.000 .000 \\
\hline 2016 & 2.250 .000 \\
\hline 2017 & 2.435 .625 \\
\hline 2018 & 2.647 .767 \\
\hline 2019 & 2.860 .382 \\
\hline
\end{tabular}

Source : Badan Pusat Statistik Sulawesi Selatan, 2020

The amount of GRDP based on the business field has increased every year, where in 2019 it was a year with a fairly high nominal increase from the previous years, namely $44,832,070$ then in 2010 was the year with the lowest nominal from the following years due to production factors in the industry experiencing quality improvement followed by the addition of adequate equipment and supported by better changes in economic structure from year to year. 
Sitti Aisyah, Sulastri, Tracing the Labor Absorption Rate in the Medium and Large Industrial Sectors.

Table 4

Industrial sector GDP growth percentage based on constant prices in the period 2010-2019

\begin{tabular}{cccc}
\hline No & Year & $\begin{array}{c}\text { Total PDRB } \\
\text { (Billion Rp) }\end{array}$ & $\begin{array}{c}\text { Percentage of growth } \\
\text { PDRB (\%) }\end{array}$ \\
\hline 1 & 2010 & $23,604,460$ & - \\
\hline 2 & 2011 & $25,736,566$ & 0,90 \\
\hline 3 & 2012 & $27,966,146$ & 0,86 \\
\hline 4 & 2013 & $30,545,257$ & 0,92 \\
\hline 5 & 2014 & $33,293,323$ & 0,89 \\
\hline 6 & 2015 & $35,547,211$ & 0,67 \\
\hline 7 & 2016 & $38,473,771$ & 0,82 \\
\hline 8 & 2017 & $40,407,185$ & 0,50 \\
\hline 9 & 2018 & $40,788,012$ & 0,09 \\
\hline 10 & 2019 & $44,832,070$ & 0,99 \\
\hline
\end{tabular}

Source: Badan Pusat Statistik Sulawesi Selatan, 2020.

Table 5

Number of Medium and Large Industrial Sector Business Units in South Sulawesi Province 2010-2019

\begin{tabular}{cc}
\hline Year & Total Company \\
\hline 2010 & 293 \\
\hline 2011 & 285 \\
\hline 2012 & 291 \\
\hline 2013 & 326 \\
\hline 2014 & 333 \\
\hline 2015 & 338 \\
\hline 2016 & 615 \\
\hline 2017 & 422 \\
\hline 2018 & 275 \\
\hline 2019 & 565
\end{tabular}

Source : Badan Pusat Statistik Sulawesi Selatan, 2020 
The quantity of medium and large industrial sector business units has fluctuated. where in 2016 was the year with the highest increase from other years and the lowest in 2018 with the number of business units of 275 . The number of business units in South Sulawesi province has fluctuated quite a bit, where from 2010 to 2016 has increased every the year then the years after that began to fluctuate until 2019.

The results of testing the independent variable hypothesis partially on the dependent variable, while the analysis obtained is as follows:

1) The variable number of business units (X1) has a significant value of $0.038<0.05$ and a tcount of 2.654> t table of 2.446, so it can be concluded that there is a positive and significant effect of the number of business units on employment in the industrial sector.

2) The provincial minimum wage variable $(X 2)$ has a significance value of 0.002 $<0.05$ and a tcount of $-5.351<$ t table 2.446 so that it can be concluded that it has a negative and significant effect on employment in the industrial sector.

The economic growth variable (X3) has a significance value of $0.004<0.05$ and a tcount of $-4.429<\mathrm{t}$ table 2.446 so it can be concluded that there is a negative and significant effect of economic growth on employment in the industrial sector.

Table 6

Coefficients $^{\mathrm{a}}$

\begin{tabular}{lrrrrrrr}
\hline & \multicolumn{2}{c}{$\begin{array}{c}\text { Unstandardized } \\
\text { Coefficients }\end{array}$} & \multicolumn{2}{c}{$\begin{array}{c}\text { Standardized } \\
\text { Coefficients }\end{array}$} & & \\
\cline { 2 - 5 } & B & Std. Error & Beta & t & Sig. \\
\hline 1 (Constant) & 26.664 & 4.772 & & & 5.588 & .001 \\
\hline Number of Business Units & .769 & .290 & .638 & 2.654 & .038 \\
\hline Provincial Minimum Wage & -2.092 & .391 & -2.297 & -5.351 & .002 \\
\hline Economic Growth & -1.288 & .284 & -1.609 & -4.529 & .004
\end{tabular}

a. Dependent Variable: Penyerapan Tenaga Kerja Sektor Industri

Source: Output SPSS 16 data processed 2020 
Table 7

Model Summary

\begin{tabular}{|c|c|c|c|c|c|}
\hline Model & $\mathrm{R}$ & R Square & $\begin{array}{l}\text { Adjusted R } \\
\text { Square }\end{array}$ & $\begin{array}{l}\text { Std. Error of the } \\
\text { Estimate }\end{array}$ & $\begin{array}{l}\text { Durbin- } \\
\text { Watson }\end{array}$ \\
\hline 1 & $.917^{a}$ & .842 & .762 & .16956 & 2.550 \\
\hline
\end{tabular}

a. Predictors: (Constant), Economic Growth, Number of Business Units, Provincial Minimum Wage

b. Dependent Variable: Industrial Sector Labor Absorption

Source: Output SPSS 16 processed data 2020

a. Test the coefficient of determination $\left(R^{2}\right)$

The coefficient of determination test in general is to measure the ability of the independent variables in explaining the dependent variable. The coefficient of determination of all independent variables is determined by the value of $R$ Square. The results of the coefficient of determination can be seen in the table. The coefficient of determination seen from the $\mathrm{R}$ Square value is 0.917 , which means that the variable number of business units, the amount of minimum wages and economic growth to explain the labor absorption variable is $91.7 \%$. The remaining $8.3 \%$ can be explained by other variables outside of the existing variables of this study.

\section{The effect of the number of business units on the employment of} medium and large industrial sectors in South Sulawesi

From the results that have been obtained, it is stated that the variable number of business units has a significant effect on labor absorption in a positive direction. Significant value can be seen in table 4.6. Based on the partial hypothesis test analysis $t$ obtained a significance value of $0.038<0.05$, so it can be said that there is an effect of the number of business units on employment in the industrial sector.

This research is in line with the theory put forward by Ashraf et al., (2020) which states that increasing the number of business units will increase the amount of output produced so that employment will increase and will reduce unemployment. This is in line with research conducted by Azoulay et al., (2019) and Tri (2004) which states that in relation to labor absorption it is influenced by the number of business units. The relationship between the number of business units and the number of workers is positive. 


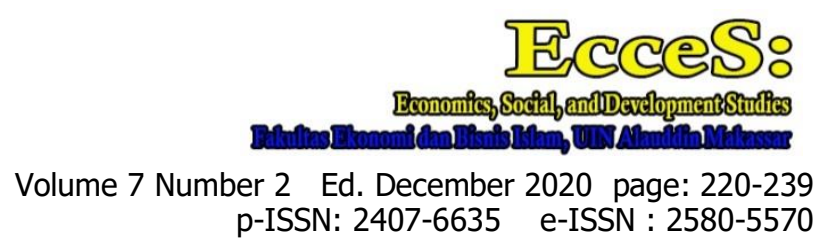

Another research that is in line is research conducted by Setiyadi (2013), Hendren and Sprung-Keyser (2020) from their research suggesting that the value of the number of business units can have a statistically significant effect on employment in industry by $95 \%$ ( $a=5 \%$ ). This is then in accordance with the initial hypothesis which has been determined that an increase in the number of business units has a positive and significant effect on employment in the cigarette industry sector in Kudus. Then supported by research conducted by Sugiharto (2017) in the results of his research stated that the number of business units has a positive and significant effect on labor absorption, meaning that the more the number of business units in the industrial sector in an area, the more labor is needed. However, these findings contradict Marshall's idea that the number of business units is not necessarily directly proportional to labor absorption, because labor is absorbed not based on quantity, but on productivity (Clairmont, 1994; Davis, 2006; Epstein, 2008; Mark, 2010; Melkevik, 2017; Horodecka and Śliwińska, 2019; Solo, 1975; Tănăsescu, 2012).

\section{The influence of the provincial minimum wage on the employment of} medium and large industrial sectors in South Sulawesi

The provincial minimum wage variable has a significant effect on labor absorption in a negative direction. The significant value can be seen in table 4.6 which shows a significant wage variable, namely $0.002<0.05$, so it can be said that the wage variable has a significant effect on labor absorption in the medium and large industrial sector in South Sulawesi.

Based on the results of the test, it shows that wages have a negative effect on labor absorption, which means that it is not in accordance with the hypothesis that has been proposed. This research is not in line with research conducted by Chusna (2013) which states that there is a significant and positive influence on employment in the industrial sector. The research that is in line with this research is the theory put forward by Payaman (2002) which states that wages have an influence on job opportunities. If the higher the level of wages set, the effect on the increase in production costs, as a result companies will reduce their workforce, which results in lower levels of employment opportunities. So it is assumed that the level of wages has a negative effect on job opportunities.

This is also in line with previous research conducted by Putra (2012) which shows that the minimum wage has a negative effect on labor absorption in the small and medium 
Sitti Aisyah, Sulastri, Tracing the Labor Absorption Rate in the Medium and Large Industrial Sectors.

industrial sector in the city of Semarang, which means that the increase in wages, the absorption of labor actually decreases. This is because the greater the wages that must be paid to workers, the lower the level of profit earned by the industrial sector.

Another study that is in line with this research was conducted by Wiguna (2019) which states that wage variables have a negative and significant effect on labor absorption in the small and medium industrial sector in East Java and are then supported by research conducted by Sugiharto (2017) in the results. His research states that the minimum wage has a negative and significant effect on the absorption of labor in small and medium industries in Central Kalimantan Province, which means that the size of a wage affects the absorption of labor.

\section{CONCLUSION}

The number of business units has a significant and positive effect on the rate of employment in the medium and large industrial sectors in South Sulawesi in 2010-2019. UMP has a significant and negative effect on the rate of employment in the medium and large industrial sectors in South Sulawesi in 2010-2019. Economic growth has a significant effect and is negatively related to the rate of employment in the medium and large industrial sectors in South Sulawesi. For the community, it is hoped that this research can add insight and knowledge about labor absorption, both in terms of labor itself and the factors behind the absorption of labor which then becomes an evaluation for each individual in determining what should be considered to be a part. of the labor. The provincial government of South Sulawesi through this research is expected to be taken into consideration in making a policy regarding employment and related industrial sectors. So that in this case the government can increase the number of workers and can reduce unemployment. Thus, the government should design an industrialization policy direction that should be more inclusive, the incoming investment should be based on empowering local workers, reducing unemployment, creating more expansive employment opportunities and synergizing local economic development. 


\section{REFERENCES}

Anwar, A.F. and Nursini, N., 2018. Mengungkap Penghidupan Petani Miskin Pedesaan; Sebuah Kajian Sosial Ekonomi. EcceS (Economics, Social, and Development Studies), 5(1), pp.1-21.

Arsyad, Lincollin. 2010. Ekonomi Pembangunan. Yogyakarta: UPP STIM YKPN.

Ashraf, N. et al. 2020. Negotiating a better future: How interpersonal skills facilitate

intergenerational investment', Quarterly Journal of Economics, 135(2), pp. 10951151. doi: 10.1093/qje/qjz039.

Azoulay, P. et al. (2019) 'Public R\&D Investments and Private-sector Patenting: Evidence from NIH Funding Rules', Review of Economic Studies, 86(1), pp. 117-152. doi: 10.1093/restud/rdy034.

Badan Pusat Statistik (BPS) Indonesia. Indonesia Dalam Angka. 2019. Jakarta.

Badan Pusat Statistik (BPS) Provinsi Sulawesi Selatan. 2020. Sulawesi Selatan Dalam Angka. Makassar. BPS Sulawesi Selatan.

Chusna, Arifatul. 2013. Pengaruh Laju Pertumbuhan Sektor Industri, Investasi, Dan Upah Terhadap Penyerapan Tenaga Kerja Sektor Industri Provinsi Jawa Tengah Tahun 1980-2011". Skripsi. Semarang. Fakultas Ekonomi Universitas Negeri Semarang.

Clairmont, F.F., 1994. Alfred Marshall: Rise and Fall of Neoclassical Dogma. Econ. Polit. Wkly. 29, 34-39.

Davis, J. B. 2006. The turn in economics: Neoclassical dominance to mainstream pluralism?', Journal of Institutional Economics, 2(1), pp. 1-20. doi: 10.1017/S1744137405000263.

Dina, H., 2015. Analisis Faktor-Faktor Yang Mempengaruhi Penyerapan Tenaga Kerja Sektor Industri Manufaktur Di Sumatera Barat (Doctoral dissertation, UPT. Perpustakaan).

Dimas Nenik, Woyanti. , 2009. Penyerapan tenaga kerja di DKI Jakarta. Jurnal Bisnis dan Ekonomi Vol. 16. No 1 Hal.32-41. 
Sitti Aisyah, Sulastri, Tracing the Labor Absorption Rate in the Medium and Large Industrial Sectors.

Epstein, R. A. 2008. The neoclassical economics of consumer contracts', Minnesota Law Review, 92(3), pp. 803-835.

Hau, H., Huang, Y., Wang, G., 2017. Firm Response to Competitive Shocks: Evidence from Chinaas Minimum Wage Policy. SSRN Electron. J. 1-45.

Hendarmin, H., 2019. Dampak Pertumbuhan Ekonomi, Aglomerasi, dan Modal Manusia Terhadap Ketimpangan Pendapatan Antar Kabupaten/Kota Di Provinsi Kalimantan Barat. EcceS (Economics, Social, and Development Studies), 6(2), pp.245-271.

Hendren, N. and Sprung-Keyser, B. (2020) 'A Unified Welfare Analysis of Government Policies*', The Quarterly Journal of Economics, 135(3), pp. 1209-1318. doi: 10.1093/qje/qjaa006.

Horodecka, A. and Śliwińska, M. 2019. Fair Trade phenomenon - limits of neoclassical and chances of heterodox economics', Studia z Polityki Publicznej, 3(3(23)), pp. 9-37. doi: 10.33119/kszpp.2019.3.1.

Kairupan, Siestri Pristina. 2013. Produk Domestik Bruto, Inflasi, Dan Belanja Daerah Pengaruhnya Terhadap Kesempatan Kerja Di Sulawesi Utara Tahun 2000-2012. Jurnal EMBA. Universitas Sam Ratulangi Manado.

Mankiw, N. Gregory. 2006. Makro Ekonomi . Edisi 6. Jakarta. Erlangga.

Mark R., R. 2010. Neoclassical Theory and the Optimizing Peasant: An Econometric Analysis of Market Family Labor Supply in a Developing Country', The quarterly Journal of Economics, 94(1), pp. 31-55.

Melkevik, $\AA$. 2017. The fictitious liberal divide: Economic rights are not basic', Erasmus Journal for Philosophy and Economics, 10(2), pp. 1-23. doi: 10.23941/ejpe.v10i2.287.

Nurrohman Riyadi, Arifin Zainal. 2010. Analisis Pertumbuhan Ekonomi Dan Penyerapan Tenaga Kerja Di Provinsi Jawa Tengah. Jurnal ekonomi Universiitas Muhammadiyah Malang.

Payaman, J. Simanjuntak. 2002. Pengantar Ekonomi Sumber Daya Manusia. Jakarta: Penerbit FE UI. 
Paramita Perwanti, Putu, Ayu. 2009. Analisis Kesempatan Kerja Sektoral Di Kabupaten Bangle Dengan Pendekatan Pertumbuhan Berbasis Ekspor. Jurnal Ekonomi Pembangunan Vol 5 No 1. Fakultas Ekonomi Universitas Udayana Denpasar.

Pratomo, Devanto Shasta \& Saputra Adi, Putu Mahardika. 2011. Kebijakan Upah Minimum Untuk Perekonomian Yang Berkeadilan: Tinjauan UUD 1945. Journal Of Indonesian Applied Economics (Vol.5 No.2 Oktober 2011). Universitas Brawijaya.

Purwasih, Herawati. Soesatyo, Yoyok. 2017. Pengaruh Pertumbuhan Sektor Industri Terhadap Penyerapan Tenaga Kerja Di Kabupaten Sidoarjo. Jurnal Pendidikan Ekonomi. Universitas Negeri Surabaya.

Putri, N.A. and Soelistyo, A., 2018. Analisis Pengaruh Upah, Pdrb, Dan Investasi Terhadap Penyerapan Tenaga Kerja Dikawasan Gerbangkertasusila Tahun 2012-2016. Jurnal Ilmu Ekonomi JIE, 2(3), pp.357-371.

Putra, R.E., 2012. Pengaruh Nilai Investasi, Nilai Upah, dan Nilai Produksi Terhadap Penyerapan Tenaga Kerja Pada Industri Mebel di Kecamatan Pedurungan Kota Semarang. Economics Development Analysis Journal, 1(2).

Rakhmawati, Atifatur, Boedirochminarti, Arfida. 2018. Analisis Tingka Penyerapan Tenaga Kerja Sektor Industri Di Kabupaten Gresik. Jurnal IImu Ekonomi. Vol.2 Jilid 1 Hal. 74-82.

Saputri, Oktaviana Dwi \& Rejeningsih, Tri Wahyu. 2008. Analisis Penyerapan Tenaga Kerja Di Kota Salatiga. Jurnal JEKT.

Sugiharto, S.D. and M Ec, D., 2017. Penyerapan Tenaga Kerja Provinsi Kalimantan Tengah dan Faktor-Faktor yang Mempengaruhinya (Doctoral dissertation, Universitas Muhammadiyah Surakarta).

Setiyadi, R.I. and Santosa, P.B., 2013. Analisis Penyerapan Tenaga Kerja Pada Industri Rokok Di Kabupaten Kudus Tahun 1993-2010. Diponegoro Journal of Economics, 2(1), pp.153-164.

Solo, R. A. 1975. Neoclassical Economics in Perspective', Journal of Economic Issues, 9(4), pp. 627-644. doi: 10.1080/00213624.1975.11503316.

Sukirno, Sadono. 2000. Makroekonomi Modern. Jakarta: PT Raja Grafindo Persada. 
Sitti Aisyah, Sulastri, Tracing the Labor Absorption Rate in the Medium and Large Industrial Sectors.

Sukirno, Sadono. 2006. Ekonomi Pembangunan. Jakarta. Prenadamedia Group.

Sukirno, Sadono. 2016. Makroekonomi Modern. Jakarta : Penerbit Rajawali Pers.

Sumarsono, Sonny. 2003. Ekonomi Manajemen Sumberdaya Manusia Dan Ketenagakrjaan. Yogyakarta. Graha IImu.

Tri, Wahyu Rejekiningsih. 2004. Mengukur Besarnya Peranan Industri Kecil Dalam Perekonomian Di Provinsi Jawa Tengah. Semarang. Jurnal Dinamika Pembangunan, 2004) Vol. 1. No.2

Todaro, Michel P. 2003. Pembangunan Ekonomi Di Dunia Ketiga. Jakarta : Ghalia Indonesia.

Taschereau-Dumouchel, M., 2015. The Union Threat. SSRN Electron. J.

Tănăsescu, G. 2012. Liberal neoclassicism and the current policy of "neoclassical synthesis"', European Journal of Science and Theology, 8(SUPPL. 1), pp. 151-161.

Wiguna, A.B., 2019. Penyerapan Tenaga Kerja Industri Provinsi Jawa Timur: Apakah Upah Minimum Masih Menjadi Faktor Penentu?. EcceS (Economics, Social, and Development Studies), 6(2), pp.214-229. 